\title{
Peter Holland: a pioneer of occupational medicine*
}

\author{
Robert Murray
}

\begin{abstract}
The earliest recorded occupational health service in this country was that established in a cotton spinning factory at Quarry Bank Mill in Cheshire. The mill was built in 1784 by Samuel Greg and his partners. They employed local labour and also some parish apprentices. Happily, Samuel Greg was a good christian and, having created a modern factory and a model village with a church and a school, he was equally concerned for the physical welfare of his employees. Accordingly, he appointed a doctor to make pre-employment examinations of the apprentices and to visit regularly to deal with the health problems of a community of some $\mathbf{4 0 0}$ people. The man he chose was Peter Holland of Sandlebridge, who had served his medical apprenticeship under Dr Charles White of Manchester. The first record of the employment of a doctor was in 1796, but from 1804 to 1845 (doubtless in response to the early factory legislation) each visit of the doctor was entered in a day book with either an indication of fitness to work or details of the treatment required. The complete record consists of two hardback foolscap notebooks that provide a fascinating insight into the medical practice of the times when the industrial revolution was just getting under way. One of the more interesting features is the preservation of medical secrecy. Dr Holland made his comments on the case in shorthand and his instructions in longhand. By a fortunate coincidence the key to the shorthand was discovered and this has now been largely transcribed. Although much of the content of the diaries is the day by day practice of medicine at the time, there are many illuminating glimpses of the early practice of occupational medicine.
\end{abstract}

^Based on the Donald Hunter Memorial Lecture, 1986.

South Hill, Church Road, Newton Green, Sudbury, Suffolk CO10 0QP

R Murray
When I told Donald Hunter of the discovery of Peter Holland's diaries in 1950, he was, as always, enthusiastic. By that time I had discovered something of Peter Holland's life and I said that the only thing that was lacking was a picture of him. About a month later Donald, in his usual miraculous way, presented me with a silver point engraving of my subject (fig 1), who was the uncle of Mrs Gaskell, the father of Sir Henry Holland, the grandfather of the first Viscount Knutsford, and the great great great grandfather of the fourth Viscount, who was then chairman of the Board of Governors of the London Hospital. Donald had recognised the connection and spoken to his chairman, who came up with the picture. This is the direct connection between Donald Hunter and Peter Holland, the head of the first recorded occupational health service in the United Kingdom.

\section{Cruelty to children}

The early years of the Industrial Revolution-which started as a textile revolution following the inventions of Kay, Arkwright, Hargreaves, Crompton and others-are associated in the minds of most of us with cruelty to children. The first cotton mills were built where there was a source of water power. (It is interesting to note in passing why they are called mills when they did not "mill" anything. The only machinery known at the time was for grinding (milling) of corn, either by wind or water power so that the new machinery was given the same generic, if inaccurate, term.) Inevitably this meant that there were few local centres of population to provide workpeople.

The workhouses provided the convenient answer to the labour problem. The machines were so simple in operation that they could easily be operated by children and, thanks to the efforts of Jonas Hanway, Charles Coram, and others, the workhouses were filled with an embarrassment of orphans. The cry for labour from the so called "jenny gentry" found a heartfelt response from the Boards of Guardians who saw in this Macedonian call the opportunity to disembarrass themselves of the expensive and unwanted children who thronged their workhouses. (I recognise that I am doing an injustice to many 


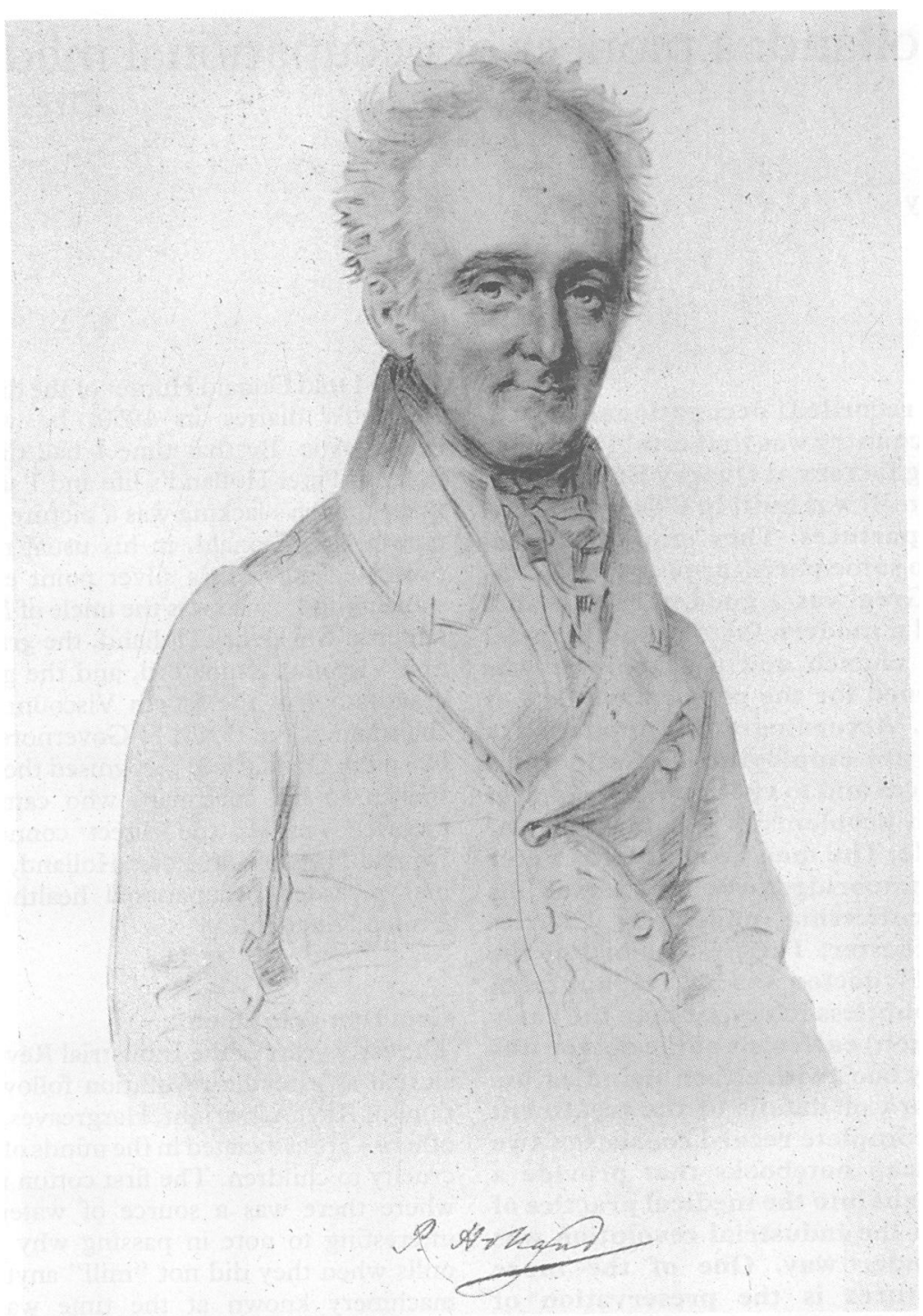

Figure 1 Peter Holland.

worthy citizens who took their responsibility seriously and intended that these children should be properly apprenticed to a trade, but it is the evil that men do that lives after them.)

There are two classical descriptions of cruelty to cotton mill apprentices, Robert Blincoe by John Brown $^{1}$ and Michael Armstrong by Mrs Frances Trollope, ${ }^{2}$ the mother of Anthony Trollope. The interesting feature, as indicated in a review of these publications, ${ }^{3}$ is that, although the early histories of the two boys are different, the descriptions of their treatment in the mill to which they were apprenticed are so remarkably similar as to suggest some element of plagiarism on the part of Mrs Trollope. For example, Robert Blincoe's mill owner was " $\mathrm{Mr}$ Ellice Needham", Michael Armstrong's "Elgood Sharpton"; Robert's overlooker was "Robert Woodward", Michael's "Woodcomb". The conditions were the same; the remoteness of the mill; the cruelty of the overlookers with strap and billy roller; the competition with the pigs for scraps. The illustration (fig 2 ) is from Trollope ${ }^{2}$ and the following description is from Brown: " The store pigs and the apprentices used to fare pretty much alike, but when the swine were hungry they used to speak and grunt so loud they obtained the wash first to quiet them. The apprentice could be intimidated and made to keep still. The fattening pigs fared luxuriously compared with the 


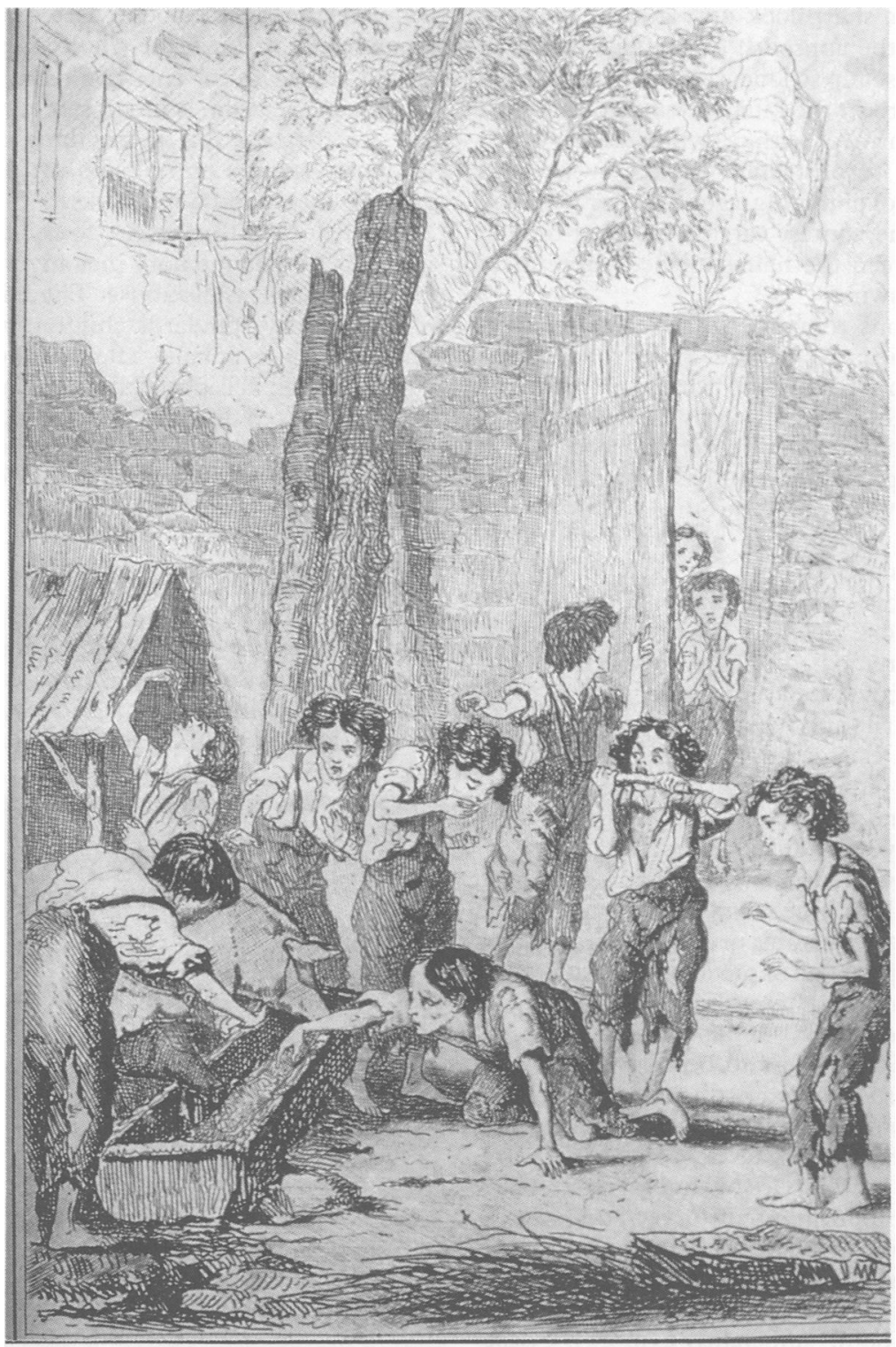

Figure 2 Make haste, young'un, or they won't leave a turnip paring for us.

apprentices. They were often regaled with meatballs made into dough and given in the shape of dumplings. Blincoe and others who worked in a part of the mill whence they could see the swine served, used to say to one another 'The pigs are served; it will be our turn next'. Blincoe and those who were in a part of the building contiguous to the pigsties used to keep a sharp eye upon the fattening pigs and their meatballs, and as soon as he saw the swineherd withdraw he used to slip downstairs and stealing slyly towards the trough, plunge his hand in at the loopholes and steal as many dumplings as he could grasp. The food thus obtained from a pig's trough, and perhaps defiled by their filthy chops were exultingly conveyed to the privy or the duck-hole, and there devoured with a much keener appetite than it would have been by the pigs, but the pigs, though generally esteemed the most stupid animals, soon hit upon the expedient that baffled the hungry boys; for the instant the meatballs were put into their troughs, they voraciously seized them and threw them into the dirt out of reach of the boys. Not this alone, but, made wise by repeated 
losses, they kept a sharp look-out, and the moment they ascertained the approach of the half-famished apprentices, they set up so loud a chorus of snorts and grunts it was heard in the kitchen, when out rushed the swineherd, armed with a whip, from which combined means of protection for the swine, this accidental source of obtaining a good dinner was soon lost. Such was the contest carried on for a time at Litton Mill between the half-famished apprentices and the well-fed swine."

Both publications compare the fate of these children with the African slave trade. Mrs Trollope says, "Let none dare say this picture is exaggerated till he has taken the trouble to ascertain by his own personal investigations that it is so. It is a very fearful crime in a country where public opinion has been proved [as in the African slave trade] to be omnipotent, for any individual to sit down with a shadow of doubt respecting such statements in his mind. If they be true, let each in his own little circle, raise his voice against the horrors detailed by them, and these horrors will be remedied. But woe to those who supinely sit in contented ignorance of the facts, soothing their spirits and their easy consciences with the cuckoo note 'exaggeration' while thousands of helpless children pine away their unnoted miserable lives, in labour and destitution, incomparably more severe than any ever produced by negro slavery."

Both paint pictures of the wicked employers. John Brown says of Ellice Needham, "Like most of his fraternity his origin was obscure. He is said to have arisen from an abject state of poverty, and had it been by honourable industry his prosperous fortune had redounded to his credit. Of his primeval state of poverty it was his weakness to be ashamed. By the profusion of his table and the splendour and frequency of his entertainments he seemed to wish to cover and conceal his mean descent. His house, lawns, equipage and style of living, completely eclipsed the neighbouring gentry, yet boundless as was his ostentation, he was in his heart sordidly mean and parsimonious. His cruelty in wringing from poor friendless orphans the means of supporting his guilty and unbecoming pomp sufficiently evinces the baseness of his heart. His mansion in 1803 and years later was at Highgate Wall, near Buxton in Derbyshire."

Brown describes the treatment of Robert Blincoe at the hands of the doctor: "Long before one wound had healed, similar acts of cruelty produced others, so that on many occasions his head was excoriated and bruised to a degree that rendered him offensive to himself and others, and so intolerably painful as to deprive him of rest at night however weary he might be. In consequence of such wounds his head was over-run by vermin. Being reduced to this deplorable state, some brute of a quack doctor used to apply a pitch cap or plaster to his head. After it had been on a given time, and when its adhesion was supposed to be complete, the terrible doctor used to lay forcibly hold of one corner and tear the whole scalp from his head at once. This was the common remedy; I should not exaggerate the agonies it occasioned were I to affirm that it must be equal to anything inflicted by the American savages on helpless prisoners with their scalping knives and tomahawks."

The history of this cruelty to children has become so much of a folk memory that anyone who suggests otherwise risks public abuse. There is no doubt that by present day standards children were shockingly treated. But it is equally true that there were people who, although accepting the standards of the time, which permitted the employment of children, nevertheless did much to mitigate the abuses and to put their human kindness into practical form. Such were Samuel Greg and Peter Holland.

\section{Samuel Greg (1758-1834)}

The second half of the eighteenth century was a time of great social, political, and religious upheaval, industrial expansion, and colonial activity. William Pitt, Samuel Johnson, John Wesley, Robert Burns, Joshua Reynolds, Thomas Gainsborough, William

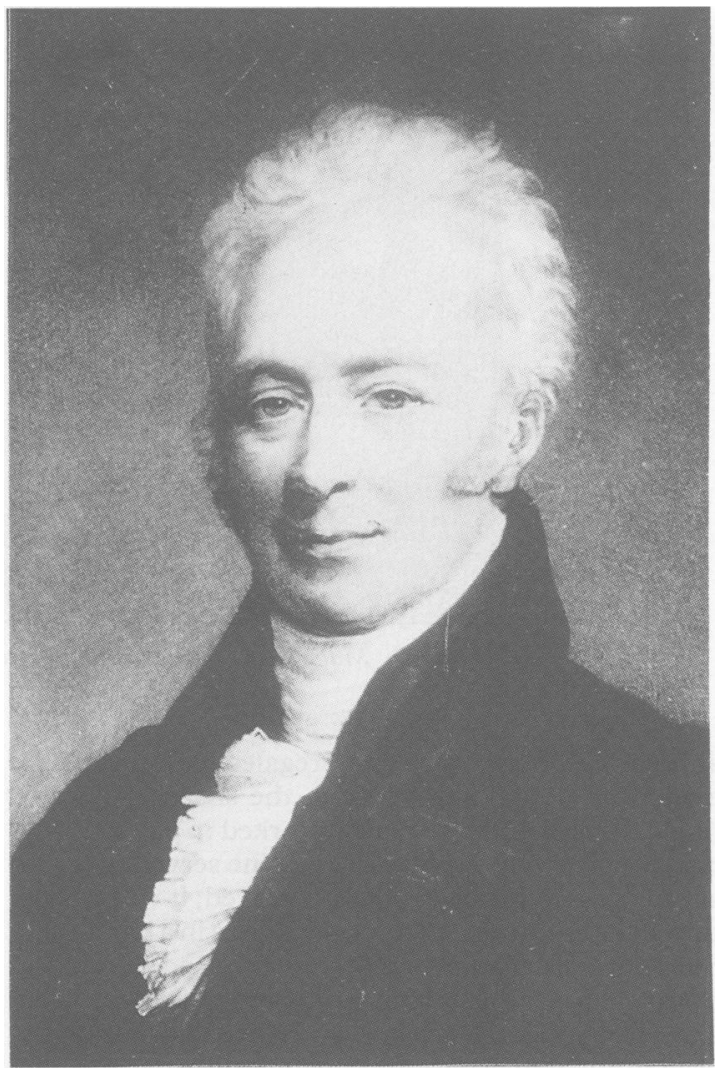

Figure 3 Samuel Greg. 


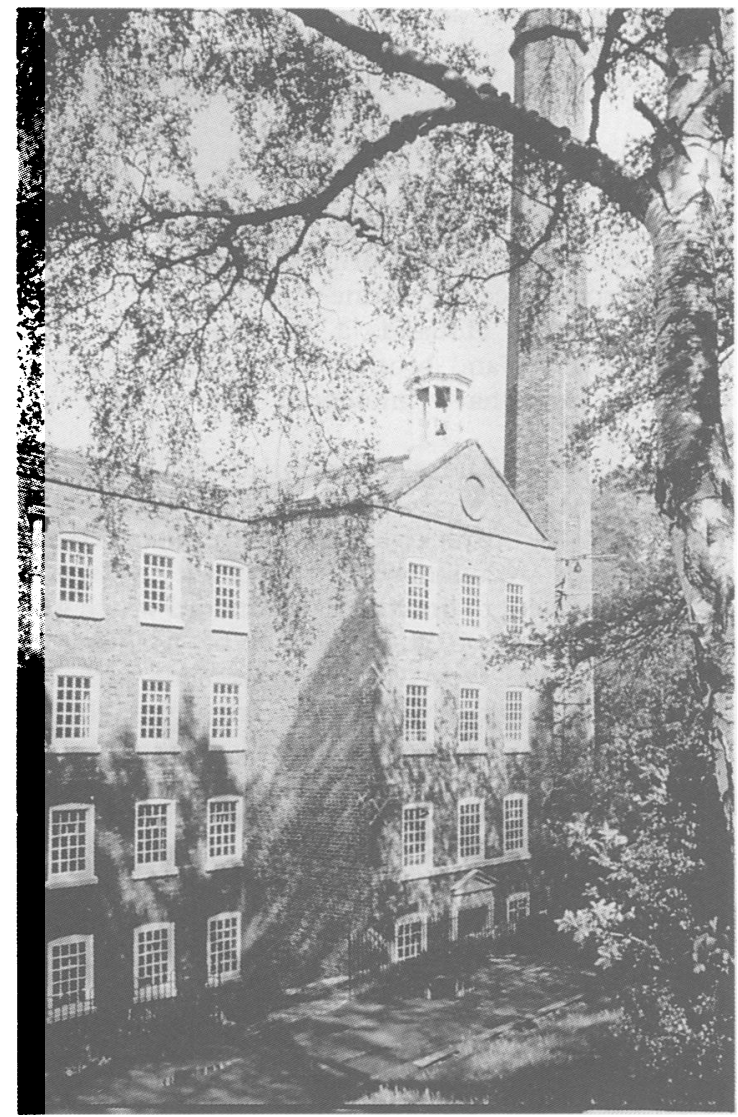

Figure 4 Quarry Bank Mill.

Blake, Robert Clive, and George Washington were all in their heyday. The Jacobite cause had perished at Culloden in 1746, the American colonies were lost in 1781 , and the French Revolution was brewing on the other side of the Channel. The inventors were laying the foundations of a water powered cotton industry while James Watt was developing the steam engine that was to have such a powerful impact on our economy as well as our geography.

Samuel Greg (fig 3) was born at the height of this ferment in 1758 and, having inherited the business of fustian manufacturing from his uncles Nathaniel and Robert Hyde, he resolved at the age of 25 to build a spinning mill. This was Quarry Bank in the village of Styal (fig 4) which I have already described. ${ }^{4}$ It is the most beautiful of cotton mills and thanks to the generosity of the Greg family, it is now National Trust property as the Quarry Bank Mill and Museum, which won the title of "Museum of the Year" in 1984. I am happy to pay tribute to its former director, David Sekers and his team of voluntary helpers for the dedicated way in which the mill has been restored, not only in terms of industrial archaeology, but also in terms of social history.

Around the mill Samuel Greg built a model village with a church, a school, housing for his workers (who were not all parish apprentices by any means), a shop (which was not a "Tommy shop" where workers were exploited by their employers until the Truck Act of 1832), a manager's house and, what is of greatest interest to us, an apprentice house. It might be said of Samuel Greg in the village of Styal as it was of Sir Christopher Wren in St Paul's Cathedral "si monumentum requiris, circumspice."

\section{Apprentices}

Much has been written about the employment of parish apprentices, rescued in their infancy by a philanthropy that only saved their lives for an unhappier fate in their youth. The Board of Guardians, saddled with a rising population in the workhouses and no doubt as anxious to equip the young people with a trade as to get them off their hands, thankfully shifted the responsibility for their maintenance to the employers clamouring for cheap labour.

The stories of Robert Blincoe and Michael Armstrong describe the conditions under which some of these "little slaves" had to work. Samuel Greg, in employing them, followed what was only common practice at the time but, under the benevolent care of his family, these children were much better off than they would have been under "the stepmotherly care of the Poor Law". Lazenby 5 says that local children were not employed to the same extent because factories were linked in the minds of the people with workhouses and so Samuel Greg had to go to the workhouses for his hands. In 1785 pauper apprentices were obtained from Newcastle-under-Lyme and the indenture of the first of these is still preserved.

It "witnesseth that Thomas Payne churchwarden of the Parish and Borough of Newcastle in the County of Stafford and Thomas Barratt Overseer of the Poor of the said Parish and Borough by and with the consent of His Majesty's Justices of the Peace for the said Borough do put and place Thomas Royley a poor child of the said parish [eleven years old] apprentice to Samuel Greg Esq of Manchester, Cotton Manufacturer with him to dwell and serve from the day of the date of these presents until the said Apprentice shall accomplish his full age of twentyone years ... During all which time the said Apprentice his Master faithfully shall serve in all lawful business according to his Wit Power and Ability and honestly orderly and obediently in all things demean and behave himself towards this said master ... and the said Samuel Greg shall and will during all the term aforesaid find provide and allow unto the said Apprentice meet, competent and suf- 
ficient Meat, Drink, Apparel, Lodging and Washing and other things necessary and fit for an apprentice."

Later on they came from contiguous parishes in the south and even as far as Norfolk and Somerset, though an Act of 1816 limited the area from which apprentices could be engaged. After 1830 the bulk of the apprentices were Irish immigrants from Liverpool. None was accepted at the mill under the age of nine. Many continued to work at the mill at the end of their apprenticeship and until late in the nineteenth century many villagers of Styal spoke with a "foreign" (that is, not local) accent.

\section{Care of apprentices}

In a letter to the Rev J Sewell, who had written to enquire about the employment of apprentices, Samuel Greg replied that "the terms on which we take them are ... [that] we keep them one month upon trial before [being] bound ... to ascertain their probable healthiness." If this appears to be a somewhat severe basis for a health service, it must be remembered that even nowadays there is seldom the grace of a month's probation and that in those days such a provision was revolutionary. Employers had to be on their guard, for parish authorities were anxious to be rid of children who were not physically fit, to the extent that "certain Poor Law officials stipulated that with every batch of children sent, a proportion had to be of this undesirable, that is, low I.Q. type" (Lazenby ${ }^{5}$ ). Some were only sent to factories when they had been misfits elsewhere.

In practice the service was not conducted on such rigid lines. There are numerous examples of children being kept for a year or more to see if their health improved. For example the notes for 28 Febuary 1833 contain the following:

"Sarah Powell, Liverpool, aged 9 Healthy now. Had inflamed eyes a year ago but they are well now and there does not seem any objection to engaging her."

"Clara Harrison, Liverpool aged 10. Has enlarged glands in the neck. Had better not be engaged at present."

"Mary Anne Hackett, Unhealthy. Must not be engaged."

"Sarah Macready. Aged 10. Eyes subject to inflammation. Not healthy." Clara Harrison and Sarah Macready, one month later, were both noted as "much more healthy than when she came" and their indentures were signed a year later.

A girl called Fanny Reece gave a great deal of trouble. She was first examined in December 1833, aged 13 and labelled as "healthy, but seems weak in intellect-doubtful." Nevertheless she was engaged, but after 1837 she appeared on almost every sick parade and seems to have spent most of her time being dosed with enemas, purgatives, emetics, or
James's powders, and having rollers (bandages), splints, poultices, lotions, liniments, blisters, and leeches applied to sundry swellings of her neck and ankle.

\section{Peter Holland (1766-1855)}

Dr Peter Holland was born at Sandlebridge near Knutsford, the second of nine children and the eldest son of Samuel Holland, a yeoman farmer. His mother's father and brother were both physicians and they may have influenced him to take up medicine.

At the age of 17 he was apprenticed to Dr Charles White of Manchester. His deed of apprenticeship was seen by Brockbank ${ }^{6}$ though its present whereabouts are unknown. After qualifying at the age of 21 he went to practice in Knutsford which was just outside the 10 mile radius of Manchester required by the terms of his agreement with $\mathrm{Dr}$ White. Either he forgot the agreement or thought it a dead letter, but he was considered to be guilty of "poaching" and in consequence he received a lawyer's letter from White demanding the forfeit of $£ 1000$. The matter was settled on "terms not stated", said to have been by the intervention of the Earl of Stamford and Warrington, whose wife Holland had attended at Dunham Hall. He became a successful practitioner and much respected in the county.

He married first in 1787 Mary, the daughter of the Reverend William Willets of Newcastle-underLyme, and a niece of Josiah Wedgwood, and had two sons and five daughters. After the death of his first wife in 1803 he married again in 1808 another Mary, daughter of Jeremiah Whittaker of Manchester, who gave him two sons and one daughter. ${ }^{7}$

There are two main sources of information about Peter Holland, one fictional and the other factual. The first is from his niece, Mrs Gaskell, the daughter of his elder sister, Elizabeth. She lost her mother within a month of her birth, and was brought up by her aunt (Peter's sister Hannah, Mrs Lumb) in Knutsford. The town (Cranford of the novel) is still redolent with memories of Mrs Gaskell; the house where she lived (now called Heathwaite, 17 Gaskell Avenue) and the Unitarian Church where she worshipped (and probably met her future husband) can still be seen. The house where Peter Holland lived is still standing. She spent much time with her uncle and it is tempting to suppose (and probably true) that she used him as the pattern for the character of $\mathbf{M r}$ Gibson, the country doctor of her posthumous novel Wives and Daughters. ${ }^{8}$ The household and the day by day life of a country doctor at the beginning of the 19th century are described in detail and it is a fascinating exercise to speculate on those features of Mr Gibson's life that were learned from direct observation of Peter Holland. 
Stripped of the more romantic trappings of the novel (the ladies said he was "the illegitimate son of a Scots duke by a French woman"), he emerges as a tall, grave, rather handsome man with black hair and a sallow complexion, not at all jovial and with a rather thistly dignity. He studies botany as a hobby and writes letters to the scientific journals. (I have searched among the medical journals of the period and found only one letter-on the subject of measles -by Peter Holland. Whether he contributed to the botanical journals or not I have been unable to discover.) He is the fashionable doctor of the neighbourhood and when the great Sir Ashley (probably based on Sir Astley Cooper) visits Lord Cumnor, Mr Gibson is invited to dine with them. The novel sheds considerable light on the old system of medical apprenticeship. "Mr Gibson kept three servants; Betty (who had been his daughter's nurse), a cook, and a girl who was supposed to be a housmaid, but who was under both the elder two and had a pretty life of it in consequence. Three servants would not have been required if it had not been Mr Gibson's habit as it had been Mr Hall's before him to take two "pupils" as they were called in the genteel language of Hollingford, "apprentices" as they were in factbeing bound by indentures and paying a handsome premium to learn their business. They lived in the house and occupied an uncomfortable ambiguous, or, as Miss Browning called it with some truth, "amphibious" position. They had their meals with $\mathrm{Mr}$ Gibson and Molly, and were felt to be terribly in the way; Mr Gibson not being a man who could make conversation, and hating the duty of talking under restraint. Yet something within him made him wince, as if his duties were not rightly performed, when, as the cloth was drawn, the two awkward lads rose up with joyful alacrity, gave him a nod, which was to be interpreted as a bow, knocked against each other in their endeavours to get out of the dining room quickly; and then might be heard dashing along the passage which led to the surgery, choking with half suppressed laughter. Yet the annoyance he felt at this dull sense of imperfectly fulfilled duties only made his sarcasm on their inefficiency, or stupidity, or ill manners, more bitter than before. Beyond direct professional instruction, he did not know what to do with the succession of pairs of young men, whose mission seemed to be to be plagued by their master consciously and to plague him unconsciously. Once or twice Mr Gibson had declined taking a fresh pupil, in the hopes of shaking himself free from the incubus, but his reputation as a clever surgeon had spread so rapidly that his fees which he had thought prohibitory, were willingly paid, in order that the young man might make a start in life, with the prestige of having been a pupil of Gibson of Hollingford."

In spite of this, $\mathrm{Mr}$ Gibson was not without a sense of humour. One delightful scene tells how a gawky apprentice, the son of an old friend of his, falls in love with the doctor's daughter and writes her a passionate letter which he entrusts to the maid for delivery. The doctor intercepts this declaration of love (resolves incidentally to take the Shakespeare out of the surgery and replace it by Dr Johnson's dictionary), and returns it to the sender with the following prescription:

$\begin{array}{ll}\mathbf{R} & \\ \text { Verecundiae } & 1 \text { ounce } \\ \text { Fidelitatis Domesticae } & 1 \text { ounce } \\ \text { Reticentiae } & 3 \text { grains }\end{array}$

M./Capiat hanc dosim ter die in aqua pura R Gibson CH

(that is, modesty, fidelity, and reticence).

The other source of information, and more interesting so far as occupational medicine is concerned, is contained in two cloth bound foolscap notebooks that I found (not without assistance) in the cellars at Quarry Bank Mill. The story is worth retelling. When I went to Manchester as $\mathrm{H}$ M medical inspector of factories, I could not but be captivated by the history of the textile industry, the evidence of which was around me every day of my working life. At that time, Ronald Lane was setting up his Department of Occupational Health and had with him Clare Sykes, an occupational health nurse fresh from her triumphs during the war in the munitions factories. She had started the Journal for Industrial Nurses and, like

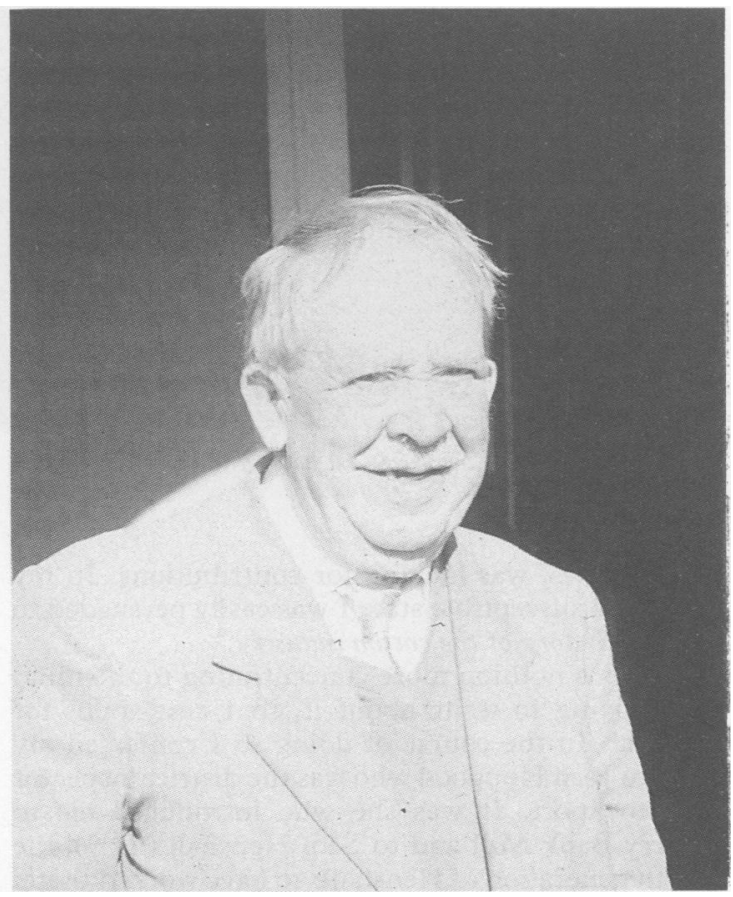

Figure 5 Samuel Henshall. 


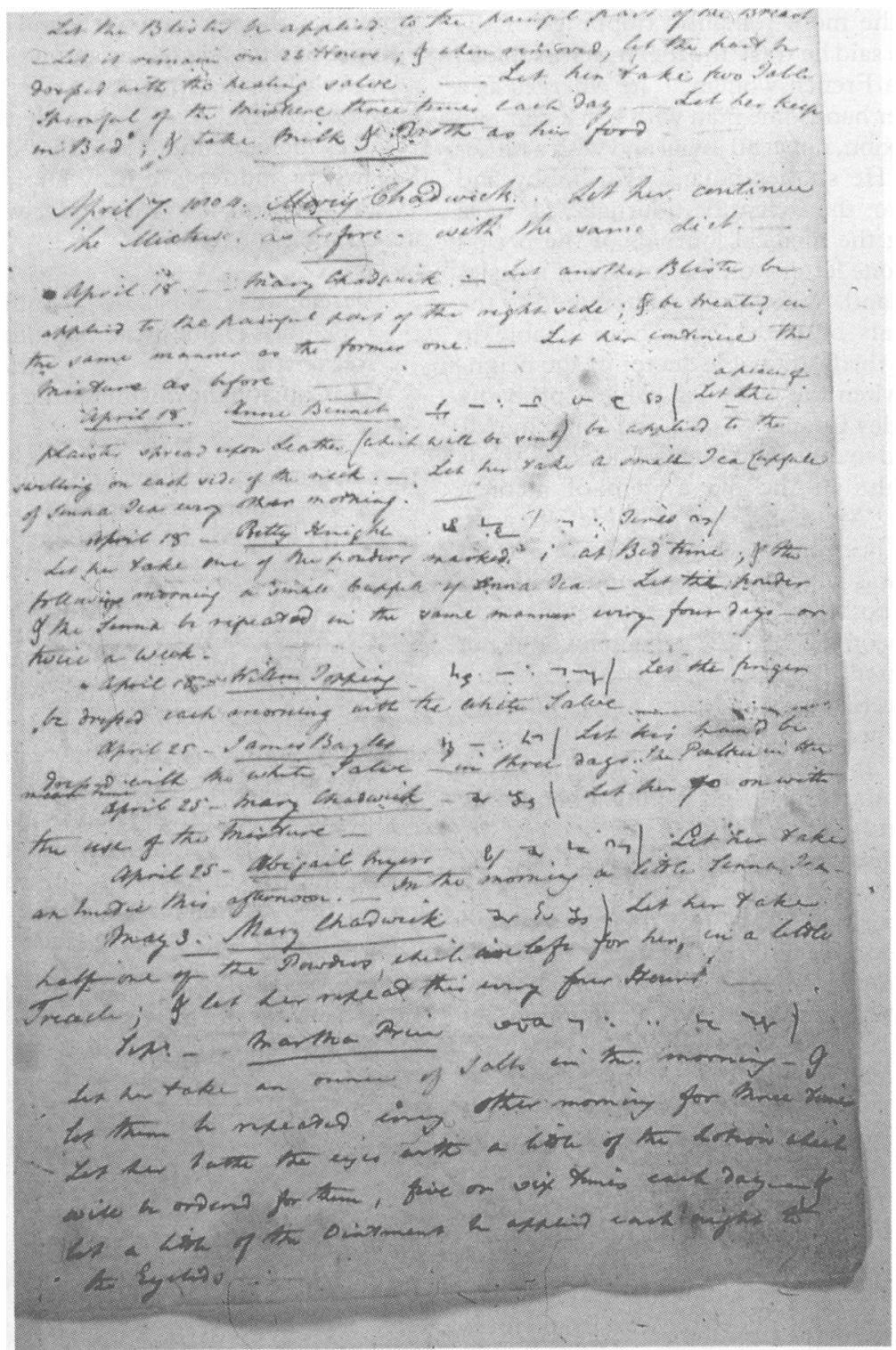

Figure 6 A page of the diary.

most editors, was looking for contributions. In my naive and susceptible state I was easily persuaded to write a History of the cotton industry. ${ }^{9}$

There is nothing more concentrating to the mind than having to write about it, so I cast about for material. In the course of doing so I confessed my lapse to Joan Hopgood who was the district inspector for Stockport. It was she who introduced me to Quarry Bank Mill and to Sam Henshall (fig 5), the fourth generation of Henshalls to have worked there. He shared my enthusiasm about the early years of the cotton industry and the employment of parish apprentices from whom he himself derived.

Fortunately the mill had not destroyed any of its papers and Henshall said that he thought he had seen some papers written by a doctor and after a couple of weekends searching in the cellars, there were the doctor's diaries. "Then felt I like some watcher of the skies when a new planet swims into his ken" and I was hooked by Quarry Bank and Peter Holland.

The first reference to the employment of a physician at the mill is a note in the account book of 
1789 of a payment of $£ 10$ per annum for a surgeon and apothecary. ${ }^{10}$ It is not clear if the recipient was Peter Holland, but by 1795 , as well as being family doctor to the Gregs, he was being paid an annual fee of 12 guineas for medical care of the apprentices.

The diaries start in 1804 (probably in response to Sir Robert Peel's Act of 1802, the Health and Morals of Apprentices Act, in order to keep a record for the "visitors" appointed under the Act). The first volume deals with 1804 to 1827 and the second from 1827 to 1845 (by which time the Act of 1844 had created the post of certifying factory surgeon), so that it forms a continuous record of an occupational health service over a period of 40 years.

The first volume is the more interesting as it is mainly in the hand of Peter Holland. The illustration (fig 6) is from the first page and the problem that confronted me is immediately obvious. It is written in a mixture of shorthand and longhand. The shorthand could not be read by any of the secretaries and after some attempts to identify it I discovered through a friend that it was the system published by Jeremiah Rich in 1642 and adapted by Philip Doddridge, the hymn writer (christians awake) who had been involved in the foundation of Warrington Academy where Peter Holland may have been a pupil (though I have not been able to confirm this).

The Rich system is described in Isaac Pitman's History of shorthand. ${ }^{11}$ By the year 1680, Rich's book, The pen's dexterity ${ }^{12}$ had reached its fifth edition and the system is said, in the title page, to have been practised by "honourable persons" and "eminent lawyers" as well as by "reverend divines". To this edition and perhaps also to previous ones, is prefixed a portrait of the author. It is indicative of much benevolence and seems to say that he was rich in goodness as well as in name. Underneath are the following lines:

Here, active and mysterious art you see Contracted in a small epitome; Soon gain'd with practice; thus the meanest wit Makes a diversion of a benefit

Thus either sex, or age, may old or young With nimble pen outpost the nimble tongue. Thus to their lasting fame it shall be said Rich lives in characters, though Rich be dead.

Pitman criticises the system for its use of arbitrary characters and indeed I have some sympathy with this view, for much burning of midnight oil has failed to decipher all of it. Enough has been transcribed, however, to recognise that this was the way in which Peter Holland made his diagnosis while giving his instructions in longhand to the occupational health nurse (probably Mrs Greg or later one of her daughters).

The transcription of the page is as follows:
March 26, 1804 Mary Chadwick pain in chest cough and fever

Let the Blister be applied to the painful part of the breast. Let it remain on 24 hours:, and when removed, let the part be dressed with the healing salve. Let her take two tablespoonfuls of the Mixture three times each day. Let her keep in bed and take milk and broth as her food.

April 7, 1804 Mary Chadwick

Let her continue the Mixture as before, with the same diet.

\section{April 181804 Mary Chadwick}

Let another Blister be applied to the painful part of the right side and be treated in the same manner as the former one ... Let her continue the Mixture as before.

\section{April 181804 Anne Bennet tumour in the neck on each side}

Let a piece of the plaister spread upon leather (which will be sent) be applied to the swelling on each side of the neck. Let her take a small tea cupful of Senna tea every other morning.

April 181804 Betty Knight ? worms of the taenia kind

Let her take one of the powders marked (i) at bedtime and the following morning a small cupful of Senna tea. Let the powder and the Senna be repeated in the same manner every four days or twice a week.

April 181804 William Topping hurt in the finger Let the finger be dressed each morning with the white salve.

April 251804 James Bayles hurt in the hand Let the hand be dressed with the white salve in three days. The poultice in the meantime

April 251804 Mary Chadwick fever lessened Let her go on with the use of the Mixture

April 251804 Abigail Myers slight fever with cough

Let her take an emetic this afternoon. In the morning a little Senna tea.

May 31804 Mary Chadwick fever still lessened Let her take half one of the powders that are left for her, in a little treacle and let her repeat this every four hours.

\section{September 1804 Martha Price inflammation of the} eyes with fever

Let her take an ounce of salts in the morning and let them be repeated every other morning for three times. Let her bathe the eyes with a little of the lotion which will be ordered for them, five or six times each day and let a little of the ointment be applied each night to the eyelids.

The second volume contains no shorthand so it is 
much easier to transcribe. It is also less interesting as Peter Holland makes less and less of a contribution. The other doctors concerned were Dr Joseph Edward Dean (who married one of Peter Holland's daughters and who, in addition to his medical practice, was also the village postmaster of Wilmslow until, with the introduction of the penny post in 1840 and the consequent increase in the volume of letters, he was obliged to give up his appointment), Dr Joseph Nightingale, who became the certifying factory surgeon in 1844, and a number of unidentifiable contributors who may have been Peter Holland's apprentices sent out to learn something of occupational medicine!

Every page has something of interest, a problem of diagnosis (what was the chincough?), „ the limitations of the pharmacopoeia, how the child reacted, or how the doctor handled the case. There is little evidence of a preventive approach but there is a great deal of evidence of a standard of care and concern far beyond the level portrayed in the literature of the times.

\section{Conclusion}

The study of the history of occupational medicine is fascinating and each of us has an opportunity to discover aspects of the subject hitherto unknown and always illuminating.

I have often been wryly amused by the final paragraph of research reports which, for a variety of reasons not unconnected with the continued life and prosperity of the research unit concerned, invariably end with the line, "more research is required." Having been involved with this research over a period of nearly 40 years, however, I recognise the validity of this customary epilogue. In following the

*Chincough was the old name for whooping cough. story of Peter Holland I realise that I have left gaps and that future occupational physicians-even if not myself-will shed further light on this happy little backwater of medical history.

I acknowledge the help of a number of people in the preparation of this paper: the late Dr Donald Hunter for the picture of Peter Holland, the late Samuel Henshall for his encouragement, $\mathrm{Mr}$ Peter Pitman for information about the history of shorthand, and Mr Keith Jones, the acting librarian of Bath University, for information about Jeremiah Rich.

1 Brown J. A memoir of Robert Blincoe, an orphan boy, sent from the workhouse of St Pancras, London at seven years of age to endure the horrors of a cotton mill through his infancy and youth with a minute detail of his sufferings; being the first memoir of the kind published: Printed for and published by J Doherty, 37 Withy Grove, Manchester, 1832.

2 Trollope Frances. The life and adventures of Michael Armstrong, the factory boy. London: Henry Colburn, 1840.

3 Murray R. Robert Blincoe and Michael Armstrong. Journal for Industrial Nurses 1954;6:147-57.

4 Murray R. Quarry Bank Mill; 1 . The story of the mill. Br J Ind Med 1958;15:293-8. 2. The Medical Service. Br J Ind Med 1959;16:61-7.

5 Lazenby WC. A social and economic history of Styal. Manchester: Thesis in Christie Library, Manchester University 1940.

6 Brockbank EM. Sketches of the lives and work of the honorary medical staff of the Manchester Infirmary 1752-1830. Manchester: University Press 1904.

7 Burkes Peerage 100th ed. London: 1950.

8 Gaskell EC. Wives and Daughters. London: John Lehmann, 1948. (First published 1866.)

9 Murray R. History of the cotton industry. Journal for Industrial Nurses 1950;part I.2:21-38, part II 3:15-30, part III 3:238-55.

10 Quarry Bank MSS. An extensive collection of documents is kept at the Mill.

11 Pitman I. History of shorthand. London: Pitman, 1847, revised 1884. 26-37 and appendix 247.

12 Rich J. Semography: or, short and swift writing. London 1642. Later editions were entitled The pen's dexterity.

Accepted 8 January 1992 